\title{
HUBUNGAN ANTARA MENYUSUI DENGAN INVOLUSI UTERI PADA IBU POST PARTUM
}

\author{
Intan Sari \\ Akademi Kebidanan Budi Mulia Prabumulih
}

\begin{abstract}
A B S T R A K
Laktasi merupakan keseluruhan proses menyusui mulai dari ASI diproduksi sampai proses bayi menghisap dan menelan ASI. Proses menyusui mempengaruhi penurunan tinggi fundus uteri. Ibu yang mengalami gangguan laktasi akan menghambat proses involusi uterus yang akan berdampak pada terjadinya perdarahan. salah satu cara untuk mencegah perdarahan masa nifas adalah dengan memberikan ASI sedini mungkin kepada bayi. Penelitian ini bertujuan untuk mengetahui hubungan antara menyusui dengan involusi uteri pada ibu post partum Rumah Sakit Umum Daerah Prabumulih. Penelitian ini merupakan penelitian survey analitik dengan pendekatan cross sectional. Populasi dalam penelitian ini adalah seluruh ibu post partum yang bersalin di Rumah Sakit Umum Daerah Prabumulih pada bulan september sebanyak 60 orang. Pengambilan sampel dilakukan dengan non probability sampling yaitu accidental sampling. Jumlah sampel adalah 30 orang ibu post partum hari ke 10 yang kemudian akan dianalisis dengan menggunakan uji chi square. Hasil penelitian menunjukkan ada hubungan antara menyusui dengan involusi uteri $(\mathrm{p}$-value $=0,001<\alpha(0,05))$. Adapun saran peneliti bagi ibu post partum, diharapkan untuk lebih meningkatkan kesadarannya untuk menyusui bayinya.
\end{abstract}

Kata kunci : Menyusui, Involusi Uteri, subinvolusi uteri, laktasi..

\begin{abstract}
Lactation is the whole process of breastfeeding starting from the milk produced until the baby's process sucks and swallows milk. The breastfeeding process affects the decrease in uterine fundus height. Mothers who experience lactation disorders will inhibit the process of uterine involution which will result in bleeding. one way to prevent postpartum bleeding is to give breast milk as early as possible to the baby. This study aims to determine the relationship between breastfeeding and uterine involution in the post partum mother of the Prabumulih Regional General Hospital. This study is an analytical survey research with a cross sectional approach. The population in this study were all post partum mothers who gave birth at the Prabumulih Regional General Hospital in September as many as 60 people. Sampling is done by non probability sampling, namely accidental sampling. The number of samples is 30 post partum mothers on the 10th day who will then be analyzed using the chi square test. The results showed that there was a relationship between breastfeeding and uterine involution ( $p$-value $=0.001<\alpha(0.05)$ ). As for researchers' suggestions for post partum mothers, it is expected to further increase their awareness to breastfeed their babies.
\end{abstract}

Keywords : Breastfeeding, Uterine Involution, uterine subinvolution, lactation

\section{PENDAHULUAN}

Masa nifas merupakan masa yang dimulai segera setelah kelahiran bayi yang meliputi mingguminggu berikutnya pada waktu saluran reproduksi kembali ke keadaan sebelum hamil. Masa nifas berlangsung selama 6 minggu atau 42 hari. Proses pemulihan pada masa nifas merupakan hal yang sangat penting bagi ibu setelah melahirkan. Pada masa nifas alat-alat genetalia eksternYa maupun interna akan berangsur-angsur pulih kembali seperti keadaaan sebelum hamil. Perubahan keseluruhan 
alat-alat genetalia tersebut biasa disebut dengan involusi, salah satunya ditandai dengan penurunan fundus uteri. Involusi disebabkan oleh kontraksi dan serabut otot uterus yang terjadi terus menerus sehingga menyebabkan kompresi pembuluh darah (Prawirohardjo, 2005).

Masa nifas hari pertama adalah masa kritis yang rentan sekali terjadi perdarahan karena kontraksi uterus yang lemah akibat berkurangnya kadar oksitosin yang di sekresi oleh kelenjar hipofise posterior. Asuhan masa nifas pada masa ini sangat diperlukan. Salah satu cara untuk mencegah perdarahan masa nifas adalah dengan memberikan pendidikan kesehatan kepada ibu nifas mengenai pemberian ASI sedini mungkin kepada bayi. Pada saat bayi menyusu, isapan bayi pada payudara akan merangsang terbentuknya oksitosin oleh kelenjar hipofisis. Oksitosin membantu involusi uterus sehingga dapat mencegah terjadinya perdarahan post partum (Wulandari, 2010).

Masa nifas merupakan salah satu bagian penting dari proses persalinan. Pada masa ini, seorang perempuan memasuki fase menjadi seorang ibu. Mengingat pentingnya masa nifas dan pertimbangan banyaknya kematian pada ibu yang terjadi pada masa nifas, maka diperlukan asuhan kebidanan yang optimal. Untuk memberi asuhan kebidanan yang optimal diperlukan pemahaman dan penguasaan ilmu pengetahuan, keterampilan, dan sikap yang profesional.

Laktasi merupakan keseluruhan proses menyusui mulai dari ASI diproduksi sampai proses bayi menghisap dan menelan ASI. Sejak terjadinya kehamilan sudah terjadi persiapan pada kelenjar mamae untuk menghadapi masa laktasi. Perubahan yang terjadi pada kelenjar mamae alveolus mamae dari lemak, pada duktus laktiverus terdapat cairan yang kadang dikeluarkan berwarna kuning (kolostrum), hipervaskulerisasi terjadi pada permukaan maupun bagian mamae, setelah partus pengaruh oksitosin mengakibatkan miopitelium kelenjar susu berkontraksi sehingga keluarlah air susu. Ibu yang mengalami gangguan laktasi dapat mengganggu proses penurunan fundus uteri. Apabila proses involusi tidak berjalan dengan baik maka akan timbul suatu keadaan yang disebut subinvolusi yang akan menyebabkan perdarahan post partum (Hanifa, 1999).

Proses involusi uteri dapat diamati dari luar yaitu dengan memeriksa fundus uteri. Segera setelah persalinan, tinggi fundus uteri setinggi pusat, pada hari ke 7 fundus uteri berada diantara pertengahan pusat dan shymphisis. Pada hari ke 10 tinggi fundus uteri sudah tidak teraba. Ibu yang memberikan ASI akan mengalami proses involusi yang baik dan lebih cepat dibandingkan dengan ibu yang tidak memberikan ASI (Wulandari, 2010).

Berdasarkan uraian di atas peneliti tertarik untuk meneliti tentang hubungan antara menyusui dengan involusi uteri pada ibu post partum di Rumah Sakit Umum Daerah Prabumulih.

\section{METODE PENELITIAN}

Penelitian ini menggunakan pendekatan Cross Sectional yaitu suatu penelitian dimana variabel sebab atau risiko dan akibat/kasus yang terjadi pada objek penelitian diukur atau dikumpulkan secara simultan dalam waktu yang bersamaan (Notoatmodjo, 2010). Penelitian ini bermaksud untuk mengetahui hubungan antara menyusui dengan involusi uteri pada ibu post partum di Rumah Sakit Umum Daerah Prabumulih.

Penelitian ini merupakan jenis penelitian survey analitik yang merupakan suatu penelitian yang mencoba mengetahui mengapa masalah kesehatan bisa terjadi, kemudian melakukan analisis hubungan antara faktor resiko dengan faktor efek.

Populasi dalam penelitian ini adalah keseluruhan ibu postpartum yang bersalin di Rumah Sakit Umum Daerah Prabumulih selama bulan September 2018 yang berjumlah 60 orang ibu postpartum.

Sampel dalam penelitian ini adalah ibu 10 hari postpartum yang bersalin di Rumah Sakit umum Daerah Prabumulih yang berjumlah 30 responden.

Penelitian ini menggunakan data sekunder, data sekunder ini diperoleh melalui medical record ibu hamil yang mengalami hiperemesis gravidarum yang pernah dirawat di Rumah Sakit Bhayangkara Palembang pada tahun 2017 dengan instrumen yang digunakan adalah check list atau format pengambilan data.

Analisis univariat bertujuan untuk mengidentifikasi setiap variabel yang diteliti dengan cara membuat tabel frekuensi dari masing-masing variabel.

Analisis yang Analisa bivariat bertujuan untuk mengetahui hubungan antara dua variabel, yaitu variabel dependen (involusi uteri) dan variabel independen (menyusui), dengan menggunakan uji Chi Square dibantu dengan program komputer SPSS.

\section{HASIL PENELITIAN}

Pada hasil penelitian ini menyajikan tentang hubungan antara menyusui dengan involusi uteri pada ibu post partum di Rumah Sakit Umum Daerah Prabumulih. Sebanyak 30 orang responden telah diteliti, yaitu ibu post partum hari ke 10 di Rumah Sakit Umum Daerah Prabumulih. Pada hasil 
Jurnal Kebidanan :Jurnal Medical Science Ilmu Kesehatan Akademi Kebidanan Budi Mulia Palembang Volume.8 No.2, Desember 2018

penelitian ini ini terdiri dari dua bagian yaitu analisis univariat dan bivariat.

\section{Analisis Univariat}

Pada penelitian ini, analisis univariat digunakan untuk memberikan gambaran tentang ibu post partum yang menyusui dan involusi uteri di Rumah Sakit Umum Daerah Prabumulih.

\section{a. Menyusui}

Distribusi frekuensi berdasarkan ibu post partum yang menyusui disajikan pada tabel berikut ini.

\section{Tabel 1Distribusi Frekuensi Berdasarkan Ibu Post Partum yang Menyusui di Rumah Sakit Umum Daerah Prabumulih.}

\begin{tabular}{clc}
\hline Menyusui & Frekuensi & $\begin{array}{c}\text { Persentase } \\
(\boldsymbol{\%})\end{array}$ \\
\hline Tidak & 6 & 20,0 \\
Ya & 24 & 80,0 \\
\hline Jumlah & 30 & 100,0 \\
\hline
\end{tabular}

Berdasarkan tabel di atas, dapat diketahui bahwa ibu post partum yang menyusui di Rumah Sakit Umum Daerah Prabumulih sejumlah 24 orang $(80,0 \%)$, sedangkan yang tidak menyusui hanya 6 orang $(20,0 \%)$.

b. Involusi Uteri

Distribusi frekuensi berdasarkan involusi uteri pada ibu post partum disajikan pada tabel berikut ini.

Tabel 2Distribusi Frekuensi Berdasarkan Involusi Uteri pada Ibu Post Partum di Rumah Sakit Umum Daerah Prabumulih

\begin{tabular}{lll}
\hline $\begin{array}{c}\text { Involusi } \\
\text { Uteri }\end{array}$ & Frekuensi & $\begin{array}{c}\text { Persentase } \\
(\mathbf{\%})\end{array}$ \\
\hline Lambat & 7 & 23,3 \\
Normal & 23 & 76,7 \\
\hline Jumlah & 30 & 100,0 \\
\hline \multicolumn{2}{r}{ Berdasarkan tabel di } & atas, dapat
\end{tabular}

diketahui bahwa ibu post partum di Rumah Sakit Umum Daerah Prabumulih sebagian besar responden mengalami involusi uteri normal, yaitu sejumlah 23 orang $(76,7 \%)$, sedangkan ibu post partum yang mengalami involusi uteri lambat sejumlah 7 orang $(23,3 \%)$.

\section{Analisis Bivariat}

Analisis bivariat pada penelitian ini digunakan untuk mengetahui hubungan antara menyusui dengan involusi uteri pada ibu post partum di Rumah Sakit Umum
Daerah Prabumulih. Untuk menguji hubungan ini digunakan uji Chi Square, dimana hasilnya disajikan berikut ini.

Tabel 3 Hubungan Antara Menyusui Dengan Involusi Uteri Pada Ibu Post Partum Di Rumah Sakit Umum Daerah Prabumulih

\begin{tabular}{|c|c|c|c|c|c|c|c|}
\hline \multirow{3}{*}{ Menyusui } & \multicolumn{4}{|c|}{ Involusi Uteri } & \multirow{2}{*}{\multicolumn{2}{|c|}{ Total }} & \multirow{2}{*}{$\begin{array}{c}\text { P- } \\
\text { value }\end{array}$} \\
\hline & \multicolumn{2}{|c|}{ Lambat } & \multicolumn{2}{|c|}{ Normal } & & & \\
\hline & $\mathbf{f}$ & $\%$ & $\mathbf{F}$ & $\%$ & $\mathbf{f}$ & $\%$ & \\
\hline Tidak & 5 & 83,3 & 1 & 16,7 & 6 & 100 & 0,001 \\
\hline $\mathrm{Ya}$ & 2 & 8,3 & 22 & 91,7 & 24 & 100 & \\
\hline Jumlah & 7 & 23,3 & 23 & 76,7 & 30 & 100 & \\
\hline
\end{tabular}

Berdasarkan tabel di atas, dapat

diketahui bahwa ibu post partum yang tidak menyusui yang mengalami involusi uteri lambat sejumlah 5 orang $(83,3 \%)$, sedangkan ibu post partum yang menyusui yang mengalami involusi uteri lambat sejumlah 2 orang (8,3\%). Berdasarkan persentase ini menunjukkan bahwa ibu yang mengalami involusi uteri lambat lebih banyak terjadi pada ibu yang tidak menyusui dibandingkan dengan ibu yang menyusui.

Berdasarkan uji Chi Square didapat $p$ value (Fisher Exact) 0,001. Oleh karena pvalue $=0,001<\alpha(0,05)$, maka Ho ditolak, artinya ada hubungan yang signifikan antara menyusui dengan involusi uteri pada ibu post partum di Rumah Sakit Umum Daerah Prabumulih.

\section{PEMBAHASAN}

\section{Analisis Univariat}

\section{a. Menyusui}

Menyusui merupakan proses fisiologis untuk memberikan nutrisi kepada bayi secara optimal. Penelitian ini dilakukan pada ibu post partum hari ke 10 di Rumah Sakit Umum Daerah Prabumulih pada bulan September sebanyak 30 responden. Didapat bahwa sebanyak 24 responden $(80,0 \%)$ yang menyusui dan sebanyak 6 responden $(20.0 \%)$ yang tidak menyusui. Dari hasil penelitian menunjukkan bahwa hampir seluruh responden yaitu 24 responden $(80,0 \%)$ menyusui bayinya dari pertama kali ASI ibu keluar sampai hari ke 10. Sewaktu bayi menyusui, ujung saraf peraba yang terdapat pada putting susu terangsang. Rangsangan tersebut oleh serabut afferent dibawa ke hipotalamus di dasar otak, lalu memacu hipofise anterior untuk mengeluarkan hormon prolaktin ke dalam darah. Melalui sirkulasi 
prolaktin memacu sel kelenjar (alveoli) untuk memproduksi air susu. Sedangkan ibu yang tidak menyusui bayinya ada 6 orang $(20,0 \%)$. Adapun hal-hal yang menyebabkan ibu yang tidak bisa menyusui bayinya setelah melewati proses persalinan adalah ASI ibu tidak keluar, puting susu ibu datar atau tenggelam, bayi dengan bibir sumbing, dan gangguan psikologi pada ibu post partum seperti post partum blues sehingga ibu tidak mau menyusui bayinya.

Selama proses kehamilan hormon prolaktin dalam plasenta meningkat tetapi ASI biasanya belum keluar kerena masih dihambat oleh kadar estrogen yang tinggi. Pada hari kedua atau ketiga pasca partum, kadar estrogen dan progesteron turun drastis, sehingga pengaruh prolaktin lebih dominan dan pada saat inilah mulai terjadi sekresi ASI. Dengan menyusukan bayi terjadi perangsangan puting susu, terbentuklah prolaktin dan hipofisis, sehingga sekresi ASI semakin lancar. Rangsangan yang ditimbulkan oleh bayi saat menyusu selain mempengaruhi hipofise anterior mengeluarkan hormon prolaktin juga mempengaruhi hipofise posterior mengeluarkan hormon oksitosin. Dimana setelah oksitosin dilepas ke dalam darah akan mengacu otot-otot polos yang mengelilingi alveoli dan duktulus berkontraksi sehingga memeras air susu dari alveoli, duktulus dan sinus menuju puting susu. Ibu yang menyusui dapat memerikan manfaat besar bagi kesehatan bayinya, bagi kesehatan ibu sendiri, bagi keluarga dan bagi negara.

\section{b. Involusi Uteri}

Involusi uteri adalah perubahan retrogreaf pada uterus yang menyebabkan berkurangnya ukuran uterus. Involusi puerperium dibatasai pada uterus dan apa yang terjadi pada organ dan struktur lain hanya dianggap sebagai perubahan puerperium (Varney's, 2004). Dari hasil penelitian yang dilakukan pada 30 responden didapatkan sebagian besar responden yaitu sejumlah 23 orang $(76,7 \%)$ mengalami involusi uteri normal. Sedangkan ibu post partum yang mengalami involusi uteri lambat sebanyak 7 orang $(23,3 \%)$. Hal ini disebabkan karena ada ibu yang tidak menyusui, ibu tidak melakukan senam nifas, psikologi ibu yang terganggu, dan ibu kurang mobilisasi.
Proses Involusi uteri dapat diamati dari luar yaitu dengan memeriksa tinggi fundus uteri. Involusi uterus disebabkan oleh kontraksi dan retraksi serabut otot uterus yang terjadi secara terus menerus sehingga mengakibatkan kompresi pembuluh darah serta iskemia, atrofi yaitu jaringan berproliferasi dalam jumlah besar kemudian mengalami atrofi sebagai reaksi terhadap pemberhentian produksi estrogen yang terjadi saat plasenta lepas (Ambarwati, 2010).

Bila uterus tidak mengalami atau terjadi kegagalan dalam proses involusi disebut dengan subinvolusi. Subinvolusi dapat disebabkan oleh infeksi, kontraksi lemah dan tertinggalnya sisa plasenta/perdarahan lanjut. Bila subinvolusi uterus tidak ditangani dengan baik, akan mengakibatkan perdarahan yang berlanjut atau postpartum haemorrhage.

\section{Hubungan Antara Menyusui Dengan Involusi Uteri Pada Ibu Post Partum}

Hubungan yang signifikan antara menyusui dengan involusi uteri pada ibu post partum di Rumah Sakit Umum Daerah Prabumulih dapat dilihat dari hasil analisis dengan menggunakan uji Chi Square dan didapatkan p-value (Fisher Exact) 0,001. Oleh karena $\mathrm{p}$-value $=0,001<\alpha(0,05)$, maka Ho ditolak, artinya ada hubungan yang signifikan antara menyusui dengan involusi uteri pada ibu post partum di Rumah Sakit Umum Daerah Prabumulih

Berdasarkan hasil penelitian dapat diketahui bahwa ibu post partum yang tidak menyusui yang mengalami involusi uteri lambat sejumlah 5 orang $(83,3 \%)$, sedangkan ibu post partum yang menyusui yang mengalami involusi uteri lambat sejumlah 2 orang $(8,3 \%)$. Berdasarkan persentase ini menunjukkan bahwa ibu yang mengalami involusi uteri lambat lebih banyak terjadi pada ibu yang tidak menyusui dibandingkan dengan ibu yang menyusui. Oleh karena itu menyusui merupakan salah satu faktor yang sangat penting dalam mempengaruhi proses involusi uteri ibu.

Kecepatan involusi uteri dipengaruhi oleh beberapa faktor, salah satunya adalah menyusui. Pada proses menyusui terjadi refleks let down dari hisapan bayi yang akan merangsang hipofise anterior mengelurkan hormon oksitosin. Hormon oksitosin yang dilepas dari kelenjar hipofisis memperkuat dan 
mengatur kontraksi uterus, mengompresi pembuluh darah dan membantu proses hemostasis. Dengan keluarnya hormon oksitosin, maka involusi uteri ibu nifas akan berjalan dengan baik (Suparyanto, 2010).

Hasil penelitian ini sesuai dengan hasil penelitian yang dilakukan oleh Amaliyah, Choyrotus (2015) tentang hubungan antara menyusui dini dengan involusi uteri pada ibu postpartum fisiologis di BPS Suharijati Bulak Banteng Lor Bhineka VI/53 Surabaya yang mengatakan bahwa menyusui dini dapat mempercepat proses involusi uteri

Efek oksitosin yang ditimbulkan dari proses menyusui menyebabkan terjadinya kontraksi dan retraksi otot uterin sehingga akan menekan pembuluh darah yang mengakibatkan berkurangnya suplai darah ke uterus. Proses ini membantu untuk mengurangi situs atau tempat implantasi plasenta serta mengurangi perdarahan. (Varney's,2003).

Penurunan ukuran uterus yang cepat tercermin dari perubahan lokasi ketika turun keluar dari abdomen dan kembali menjadi organ pelviks. Segera setelah proses persalinan puncak fundu kira-kira dua pertiga hingga tida perempat dari jalan atas diantara simfisis pubis dan umbilicus. Kemudian naik ke tingkat umbilicus dalam beberaoa jam dan bertahan hingga satu dua hari dan kemudia secara berangsur-angsur turun ke pelviks yang secara abdominal tidak dapat terpalpasi di atas simfisis setelah sepuluh hari.

Adapun kesimpulan dari penelitian ini adalah bahwa menyusui dapat mempengaruhi proses involusi uteri, tetapi selain menyusui ada juga beberapa faktor yang dapat mempengaruhi proses involusi uteri diantaranya adalah senam nifas, mobilisasi dini, psikologi, usia, paritas dan gizi. Akan tetapi disini penulis tidak melakukan penelitian terhadap faktor-faktor yang dapat mempengaruhi involusi uteri selain menyusui.

\section{KESIMPULAN}

Berdasarkan hasil penelitian yang dilakukan terhadap 30 responden mengenai hubungan antara menyusui dengan involusi uteri pada ibu post partum di Rumah Sakit Umum Daerah Prabumulih, maka dapat disimpulkan sebagai berikut :

1. Sebagian besar responden yang berjumlah 24 orang $(80,0 \%)$ menyusui bayinya.

2. Proses involusi uteri pada ibu post partum pada hari ke 10, sebagian besar normal berjumlah 23 orang $(76,7 \%)$.
3. Ada hubungan yang signifikan antara menyusui dengan involusi uteri pada ibu post partum di Rumah Sakit Umum Daerah Prabumulih karena didapatkan $\mathrm{p}$-value $=0,001<\alpha(0,05)$.

\section{SARAN}

\section{Bagi Peneliti Selanjutnya}

Perlu dilakukan penelitian lebih lanjut dengan mengikut sertakan faktor-faktor lain yang mempengaruhi proses involusi uterus misalnya usia, paritas, gizi dan menyusui, sehingga akan memperoleh hasil yang lebih optimal. Perlu adanya penelitian lebih lanjut dengan jumlah sampel yang besar sehingga dapat mewakili ibu post partum yang lebih luas.

\section{Bagi Tenaga Kesehatan atau Bidan}

Untuk tenaga kesehatan khususnya bidan, diharapkan dapat memberikan motivasi kepada ibu post partum untuk menyusui bayinya.

\section{Bagi Ibu Post Partum}

Khususnya pada ibu-ibu post partum, diharapkan dapat meningkatkan kesadarannya dalam memberikan ASI kepada bayinya, karena dengan menyusui ibu dapat memberikan manfaat besar bagi kesehatan bayinya, bagi kesehatan ibu sendiri, bagi keluarga dan bagi negara.

\section{DAFTAR PUSTAKA}

Ambarwati, E., \& Wulandari, D. 2010. Asuhan Kebidanan Nifas. Yogyakarta :Nuha Medika

Anggraini, Y. 2010. Asuhan Kebidanan Masa Nifas. Yogyakarta : Pustaka Rihama

Arikunto, S. 2006. Prosedur Penelitian Suatu Pendekatan Praktek. Jakarta : Rineka Cipta

Cuningham, G. Dkk. 2006. Obstetri Williams. Jakarta : EGC

Dinkes (2008). Profil Kesehatan Indonesia 2008. http://www.dinkesindonesia.go.id/download/ profil kesehatan 2008.pdf Diunduh pada tanggal 06 September 2018

Dinkes (2009). Profil Kesehatan Kota Semarang 2009.

http://www.dinkeskotasemarang.go.id/downl oad/profil kesehatan 2009.pdf. Diunduh pada tanggal 08 September 2018.

Hastono, S. 2001. Analisis Data. Jakarta: FKM-UI. 
Hidayat, AA. 2007. Metode Penelitian Keperawatan dan Teknik Analisis Data. Jakarta : Salemba Medika.

Huliana. 2003. Faktor-Faktor Yang Mempengaruhi Involusi Uteri di Wilayah Puskesmas Mergangsang Kota Yogyakarta. dari http://digilib.unnes.ac.id/gsdl/collect/skkripsi/ archives/HASH01fa/7c4e3e8f.dir/doc.pdf. Diunduh pada tanggal 15 November 2018.

Manuabaa, Ida Bagus gde. 1998. Ilmu Kebidanan, Penyakit Kandungan dan Keluarga Berencana Untuk Pendidikan Bidan. Jakarta : EGC.

Notoadmodjo, S. 2010. Metodologi Penelitian Kesehatan. Jakarta : Rineka Cipta.

Ola, Martina Barek.2014.Hubungan Inisiasi Menyusui Dini dengan Involusi Uteri Pada $\mathrm{Ibu}$ Postpartum.http://repository.wima.ac.id/181

Proverawati, A., \& Asfuah, S. 2009. Buku Ajar Gizi Untuk Kebidanan. Yogyakarta : Nuha Medika

Riyanto, A. 2011. Aplikasi Metodologi Penelitian Kesehatan. Yogyakarta : Nuha Medika.

Roesli, U. 2000. Ininsiasi Menyusui Dini Plus Asi Eksklusif. Jakarta : Pustaka Bunda

Santoso, S., \& Ranti, AL. 2004. Kesehatan \& Gizi. Jakarta : Rineka Cipta

Syelvi, Siti Fadma Sami.2015.Hubungan Inisiasi Menyusu Dini dengan Involusi Uterus Ibu Postpartum Normal Hari Ke 7. file:///C:/Users/User/AppData/Local/Temp/6 1-110-1-PB.pdF.

Sugiyono. 2007. Statistika Untuk Penelitian. Bandung : Alfabeta.

Sulisno, M. 2009. Dasar-Dasar Etika Dalam Praktek Keperawatan dan Kebidanan. Semarang : Hasani.

Suryani, S. 2008. Tujuan Pembangunan Millenium/ Millenium Development Goals (MDGs 2015).http://bimacenter.com/index2.php?opti on=com content $\&$ do $\mathrm{pdf}=1 \& \mathrm{id}=16$. Report by bimacenter.com.
Suyanto, S. 2008. Riset Kebidanan metodologi \& Aplikasi. Yogyakarta: Mitra Cendikia Offset.

Varney, Dkk. 2008. Asuhan Kebidanan Varney. Jakarta : EGC.

Wiknjosastro. 2005. Ilmu Kebidanan Edisi 3. Jakarta : Yayasan Bina Pustaka Sarwono Prawirohardjo 
